\title{
US Senate votes to ban pesticide tests on humans
}

The US Congress is considering whether to temporarily ban the Environmental Protection Agency (EPA) from using human tests to determine whether a pesticide should be marketed.

Lawmakers on Capitol Hill will soon decide whether to place a one-year moratorium on the conduct and use of studies that expose participants to pesticides. In most cases, trials are conducted by companies seeking to have their pesticides approved by the agency for marketing.

On 29 June, the Republican-controlled US Senate voted 60 to 37 to enact such a moratorium, in an amendment to the spending bill that funds the EPA. The amendment would prohibit the agency, beginning on 1 October, from conducting human exposure tests or using data from tests conducted by third parties in its pesticide risk assessments. An identical amendment was passed by the House in May.

"The moral and ethical issues surrounding these pesticide experiments are overwhelming," California Democratic Senator Barbara Boxer, who introduced the amendment, said after the vote. "The EPA should never have been considering them to begin with."

Companies became interested in human testing seemingly in a bid to circumvent a 1996 law that made it more difficult to use animal tests to meet agency standards for protecting vulnerable populations such as children from pesticide residues. The EPA now considers human testing data on a case-by-case basis, rejecting only experiments deemed scientifically unsound or 'fundamentally unethical' by EPA staff.
The EPA also last year announced that, along with the industry-backed American Chemistry Council, it would sponsor a study that would pay mainly low-income families in return for allowing the observation of their young children's exposure to in-home pesticides. EPA Administrator Stephen Johnson cancelled the study in April after Boxer threatened to hold up his nomination in the Senate.

Supporters of the amendment say the EPA's policy has been putting children at risk, but critics say that the amendment puts potentially important data out of regulators' reach. "Foreclosing on data that could determine the usefulness, the applicability and the toxicity of pesticides is an extremely bad idea," says Henry Miller, a research fellow at the conservative Hoover Institution.

The pesticide industry, represented by the Washington lobbying group CropLife America, adds that it is "troubled by the blatant manipulation of the facts" by Democratic senators. "Sound science and public health protections have affirmed the safety and ethics of human data studies," the group said in its statement.

CropLife also cited a 2004 report by the US National Academy of Sciences as supporting its position. That nuanced report called for an expert board of scientists and bioethicists outside the EPA to assess controversial third-party studies. The EPA has thus far rejected that recommendation in favor of in-house review. A recently leaked document of a proposed EPA rule also does not include establishing an outside board. A final version of the rule is due for publication in 2006.

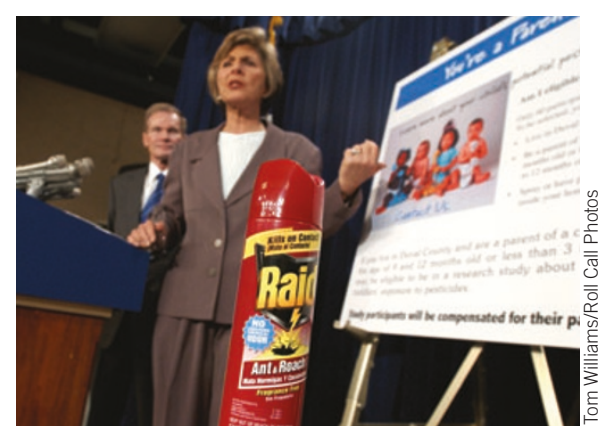

Senator Barbara Boxer has proposed a one-year moratorium on using human tests for pesticides.

Lynn Goldman, a physician who led the EPA's pesticides division from 1993-1998, says a moratorium is prudent. "A year's delay in considering these studies while the EPA puts in place some rules of the road is very reasonable," says Goldman, now a professor at the Johns Hopkins University School of Public Health.

Despite its healthy margin of support in the Senate, the Boxer amendment's passage into law is not a given. A competing amendment, sponsored by Republican Senator Conrad Burns, also passed the Senate by a vote of 57 to 40 . That version would allow the EPA to use third-party human tests in licensing decisions, within careful constraints. Unlike the Boxer amendment, it does not prohibit the EPA from conducting its own tests. A joint House-Senate committee is expected this summer to determine which version prevails.

Meredith Wadman, Washington D.C.

$\rightarrow$ http://books.nap.edu/catalog/10927.html

\section{Budget spats put European Research Council in jeopardy}

The European Commission on 18 July announced the first scientific council for the European Research Council (ERC) but researchers are increasingly concerned that the agency may not materialize if EU leaders cannot reach an agreement over the budget.

Discussions about the ERC as an agency to fund basic research began in 2002. The ERC was initially seen as functioning independently, but over time it became clear that its funds would best be channeled through the commission. In April, the commission unveiled its Seventh Framework Programme (FP7), which doubled research spending up to $€ 73$ billion by 2013 , a move widely seen as Europe's attempt to catch up to the US.

The commission, which had initially opposed plans for an ERC, also set aside \$13.5 billion to fund the ERC. But disagreements about the overall budget of the FP7 doomed that plan's prospects from the beginning. In early June, Luxembourg, which held the EU presidency until 30 June, proposed a $40 \%$ cut in the FP7 budget. The following week, a two-day budget meeting in Brussels collapsed, leaving the both the FP7 and the ERC in limbo.

Achilleas Mitsos, head of the commission's Directorate General of Research, says nothing has yet been finalized. "We have created a lot of expectations among the scientific community and don't want to disappoint them," he told Nature Medicine. But Octavi Quintana-Trías, head of health at the Directorate, says that if substantial cuts are imposed, the commission may limit the research topics covered by the ERC, advertise projects once every two or three years instead of every year, or only fund projects that encompass at least three countries in order to minimize expenses.

John Marks, director of science and strategy at the European Science Foundation, says all three possibilities are "undesirable."
Restricting research topics "creates the possibilities for political influencing of the choice of topics," he notes. Instead, he says, it might be better to limit grants to scientists who have, for example, completed between two and six years of postdoctoral training.

The Initiative for Science in Europe, established in 2002 and representing more than $\mathbf{5 0}$ European research organizations that support the ERC, on 30 June sent an appeal to the commission's top authorities. "[The ERC budget] should quickly become of the order of the budget of the larger national research councils, otherwise its impact would not be felt," it said. "The member states must realize that they cannot be penny-wise and pound-foolish.”

It is important for the ERC to be launched, adds Ernst-Ludwig Winnacker, former president of the European Heads of Research Councils - even if only with reduced funds. Xavier Bosch, Barcelona 